\title{
Sympathetic Nerve Block in Lymphedema Treatment: A Systematic Review
}

Antonio J. Forte ${ }^{1}$, Daniel Boczar ${ }^{1}$, Maria T. Huayllani ${ }^{1}$, Xiaona Lu ${ }^{2}$, Sarah A. McLaughlin ${ }^{3}$

1. Plastic Surgery, Mayo Clinic Florida - Robert D. and Patricia E. Kern Center for the Science of Health Care Delivery, Jacksonville, USA 2. Division of Plastic Surgery, Yale University, New Haven, USA 3. Surgery, Mayo Clinic Florida Robert D. and Patricia E. Kern Center for the Science of Health Care Delivery, Jacksonville, USA

Corresponding author: Antonio J. Forte, ajvforte@yahoo.com.br

\begin{abstract}
Although the sympathetic nerve system has been described as a modulator of lymphatic circulation, it has not been targeted in the treatment of lymphedema. We conducted a systematic review of publications assessing the use of sympathetic nerve block in lymphedema treatment. We hypothesized that sympathetic nerve block may be a promising treatment option for lymphedema patients. We conducted a comprehensive systematic review of the published literature on the use of sympathetic nerve block in lymphedema treatment using the PubMed database. Eligibility criteria excluded papers that reported other types of lymphedema treatment or any other anesthesiology procedure. Abstracts, presentations, reviews, and metaanalyses were also excluded. Extracted data included the year of study, country, author affiliation, type of study, patient characteristics, nerve block technique, and key findings. From 81 potential papers, eight studies fulfilled the eligibility criteria. All papers identified were clinical, reporting on a total of 187 patients. Sympathetic nerve block was proposed with local anesthetics, whether or not associated with triamcinolone. Treatment with a nerve block promoted lymphedema improvement expressed by decreased limb circumference and patient-reported outcomes. Large randomized clinical trials are still pending, but sympathetic nerve block seems to be a promising alternative for lymphedema patients who do not respond to conservative therapy.
\end{abstract}

Received 09/10/2019

Review began 09/14/2019 Review ended 09/15/2019 Published 09/19/2019

๑) Copyright 2019

Forte et al. This is an open access article distributed under the terms of the Creative Commons Attribution License CC-BY 3.0., which permits unrestricted use, distribution, and reproduction in any medium, provided the original author and source are credited.
Categories: Anesthesiology, Physical Medicine \& Rehabilitation, Plastic Surgery

Keywords: stellate ganglion block, breast cancer, lymphedema, treatment, plastic surgery, lower extremity, upper extremity, physical therapy, regional anesthesia

\section{Introduction And Background}

Lymphedema is a chronic condition that affects five to six million people in the United States alone. In developed countries, lymphedema is mostly related to cancer treatment, having incidences as high as one in every six patients undergoing surgical treatment of a solid tumor [1]. Considering that lymphedema is still an incurable disease, studies on targeted therapies have attracted the attention of the scientific community.

It is well-accepted that the physiopathology behind lymphedema is associated with inflammation and fibrosis, where normal tissue is replaced by scar tissue [2-4]. Therefore, it is reasonable that most of the targeted therapies already proposed in the literature are related to inflammation modulation, such as Th2inflammatory responses, and lymphangiogenic cytokines, such as vascular endothelial growth factor C (VEGF-C) [5-9]. Nonetheless, the translation of some of these therapies into clinical practice raises concern for metastasis in patients with a medical history of cancer [6].

The sympathetic nerve system has been described as a modulator of lymphatic circulation; however, it has not been a topic of debate in the literature about targeted therapies in the treatment of lymphedema [10-11]. Therefore, we conducted a systematic review of publications assessing the use of sympathetic nerve block in lymphedema treatment. We hypothesized that sympathetic nerve block may be a promising treatment for lymphedema patients.

\section{Review}

\section{Materials and methods}

Search Strategy

Two reviewers (D.B., M.H.) conducted independent searches using the PubMed database without timeframe limitations. The initial search included title and abstract screening, followed by a full-text review. Disagreements regarding article identification and final selection for inclusion were resolved by another reviewer (A.J.F.). The search was done using the following keywords: (((((Anesthetics) OR Local Anesthetics) OR Autonomic Nerve Block) OR Stellate Ganglion)) AND ((Lymphedema) OR Breast Cancer Lymphedema). The bibliographies of the studies that fulfilled the study eligibility criteria were also examined, looking for articles not present in our initial search. This study followed the guidelines outlined in the preferred 


\section{Cureus}

reporting items for systematic reviews and meta-analyses (PRISMA).

Selection Criteria

Eligibility criteria included studies reporting data from the use of sympathetic nerve block in the treatment of lymphedema. Therefore, we excluded papers that reported other types of lymphedema treatment or anesthesiology procedures. Abstracts, presentations, reviews, and meta-analyses were also excluded.

\section{Data Extraction and Processing}

Extracted data included the year of study, country, author affiliation, type of study, patient characteristics, nerve block technique, and key findings. Data were extracted from articles, tables, and figures by two reviewers (D.B., M.H.), with the accuracy of data entry confirmed by an additional reviewer (A.J.F.).

\section{Results}

Study Characteristics

From 81 potential papers found in the literature, eight studies fulfilled the eligibility criteria (Figure 1 , Table 1). While the first publication about sympathetic nerve block in lymphedema treatment was a case report in 1983 by authors from Sweden, most studies were conducted by groups in Asia. Interestingly, all authors were affiliated to the department of anesthesiology or rehabilitation medicine. Sympathetic nerve block was proposed with local anesthetics, whether or not associated with triamcinolone, at the lumbar spine (for lower extremity lymphedema) or at the stellate ganglion (for upper extremity lymphedema). All papers identified were clinical, reporting on a total of 187 patients. Lymphedema improvement was measured by authors through limb circumference and patient-reported outcomes. All papers identified had small sample sizes, and only two had control groups [12-13].
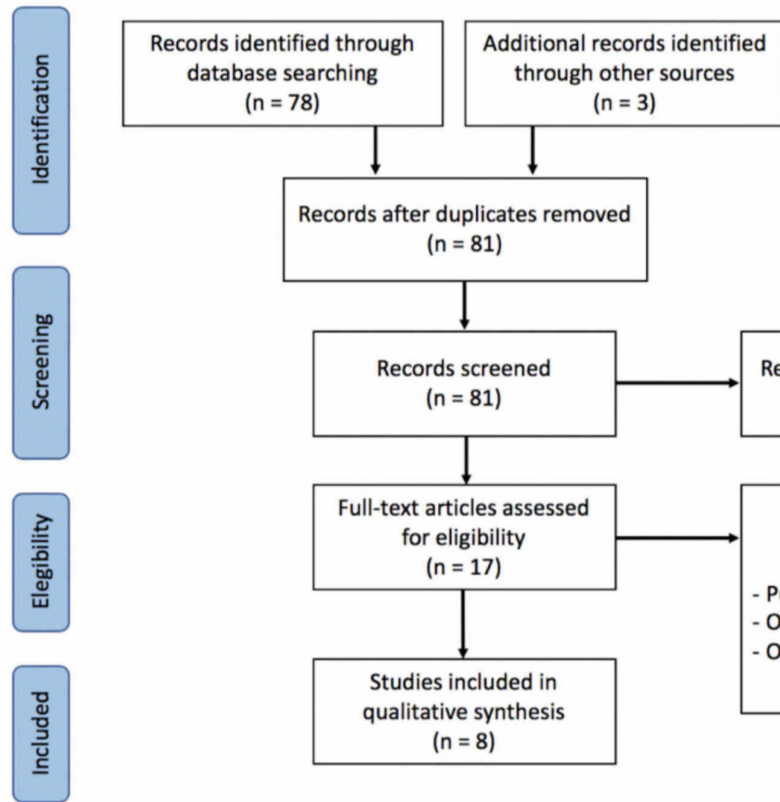

Records excluded $(n=64)$

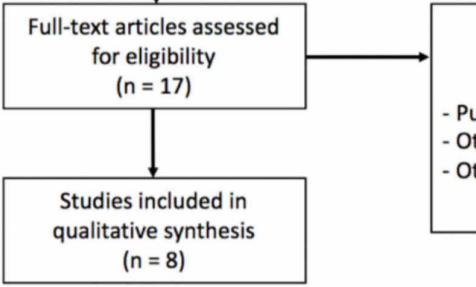

Full-text articles excluded $(n=9)$

Publication type $(n=0)$

Other topic of anesthesiology $(n=5)$

Other topic $(n=4)$

FIGURE 1: Preferred Reporting Items for Systematic Reviews and MetaAnalyses (PRISMA) Diagram 


\section{Cureus}

\begin{tabular}{|c|c|c|c|c|c|c|c|c|}
\hline Author & Year & Country & Author affiliation & Study type & Patient & Procedure & $\begin{array}{l}\text { LE } \\
\text { improvement } \\
\text { compared to } \\
\text { patient } \\
\text { baseline }\end{array}$ & Outcome compared to CTC \\
\hline $\begin{array}{l}\text { Swedborg } \\
\text { et al. [14] }\end{array}$ & 1983 & Sweden & $\begin{array}{l}\text { Department of } \\
\text { Physical Medicine } \\
\text { and Rehabilitation }\end{array}$ & Case report & 1 patient, BCRL & SGB & Yes & - \\
\hline $\begin{array}{l}\text { Asai et al. } \\
{[15]}\end{array}$ & 2001 & Japan & $\begin{array}{l}\text { Department of } \\
\text { Anesthesiology and } \\
\text { Critical Care } \\
\text { Medicine }\end{array}$ & Case report & $\begin{array}{l}1 \text { patient, Cervical } \\
\text { cancer; Bilateral } \\
\text { lower limb } \\
\text { lymphedema }\end{array}$ & $\begin{array}{l}\text { Bilateral } \\
\text { LSGB }\end{array}$ & Yes & - \\
\hline $\begin{array}{l}\text { Woo et al. } \\
\text { [16] }\end{array}$ & 2013 & Korea & $\begin{array}{l}\text { Department of } \\
\text { Anesthesiology and } \\
\text { Pain Medicine }\end{array}$ & $\begin{array}{l}\text { Prospective } \\
\text { clinical study }\end{array}$ & $\begin{array}{l}18 \text { patients, } \\
\text { Gynecological } \\
\text { cancer; Lower limb } \\
\text { lymphedema }\end{array}$ & LSGB & Yes & - \\
\hline $\begin{array}{l}\text { Choi et al. } \\
\text { [17] }\end{array}$ & 2015 & Korea & $\begin{array}{l}\text { Department of } \\
\text { Anesthesiology and } \\
\text { Pain Medicine }\end{array}$ & $\begin{array}{l}\text { Retrospective } \\
\text { study. }\end{array}$ & 35 patients, BCRL & SGB & Yes & - \\
\hline $\begin{array}{l}\text { Jin Kim et } \\
\text { al. [18] }\end{array}$ & 2015 & Korea & $\begin{array}{l}\text { Department of } \\
\text { Anesthesiology and } \\
\text { Pain Medicine }\end{array}$ & Case series & 2 patients; BCRL & SGB & Yes & - \\
\hline $\begin{array}{l}\text { Jeong-Gil } \\
\text { Kim et al. } \\
\text { [12] }\end{array}$ & 2015 & Korea & $\begin{array}{l}\text { Department of } \\
\text { Rehabilitation } \\
\text { Medicine }\end{array}$ & $\begin{array}{l}\text { Retrospective } \\
\text { matched } \\
\text { cohort study }\end{array}$ & 60 patients, BCRL & $\begin{array}{l}\text { SGB (30 } \\
\text { patients) } \\
\text { CDT (30 } \\
\text { patients) }\end{array}$ & Yes & $\begin{array}{l}\text { Both treatments improved LE. } \\
\text { Difference between them was } \\
\text { not statistically Significant. }\end{array}$ \\
\hline $\begin{array}{l}\text { Jae } \\
\text { Hyeon } \\
\text { Park et al. } \\
\text { [19] }\end{array}$ & 2015 & Korea & $\begin{array}{l}\text { Department of } \\
\text { Rehabilitation } \\
\text { Medicine }\end{array}$ & $\begin{array}{l}\text { Double- } \\
\text { blinded, } \\
\text { randomized, } \\
\text { controlled trial }\end{array}$ & 32 patients, BCRL & SGB & Yes & - \\
\hline $\begin{array}{l}\text { Myung } \\
\text { Woo } \\
\text { Park et al. } \\
\text { [13] }\end{array}$ & 2019 & Korea & $\begin{array}{l}\text { Department of } \\
\text { Rehabilitation } \\
\text { Medicine }\end{array}$ & $\begin{array}{l}\text { A randomized } \\
\text { controlled trial }\end{array}$ & 38 patients, BCRL & $\begin{array}{l}\text { SGB (19 } \\
\text { patients) } \\
\text { CDT (19 } \\
\text { patients) }\end{array}$ & Yes & $\begin{array}{l}\text { Both treatments improved LE. } \\
\text { Difference between them was } \\
\text { not statistically Significant. }\end{array}$ \\
\hline
\end{tabular}

\section{TABLE 1: Summary of Study Findings}

Abbreviations: BCRL, Breast Cancer-Related Lymphedema; LE, Lymphedema; SGS, Stellate Ganglion Blocks; CDT, Complex Decongestive Therapy; LSGB, Lumbar Sympathetic Ganglion Block

Case Reports and Case Series

The improvement of lymphedema following sympathetic nerve block has been described in two case reports and a case series. In 1983, Swedborg et al. were the first to describe a patient with breast cancer-related lymphedema who presented with a clinical improvement after a local sympathetic nerve block [14]. Jin Kim et al. described two patients with breast cancer-related lymphedema who saw a decrease in their affected limb's circumference after the second stellate ganglion nerve block [18]. They conceptualize a series of blocks to prolong the effects [18]. Asai et al. described a 70-year-old patient with bilateral lower extremity lymphedema following surgical treatment for cervical cancer that "dramatically" improved after a sympathetic ganglion block [15]. Although these studies demonstrated the positive effects of sympathetic nerve block on lymphedema, conclusions were limited by the small number of patients and the absence of control groups.

Retrospective Studies

Retrospective studies published on the use of sympathetic nerve block in lymphedema treatment demonstrated promising outcomes. Choi et al. assessed patient-reported outcomes and the arm circumference of 35 patients with breast cancer-related lymphedema who underwent sympathetic nerve 
block [17]. At two months after the nerve block, there was a statistically significant improvement in arm circumference and patient-reported outcomes. The nerve block was effective in $65.7 \%$ of patients. Interestingly, the block was more effective in patients with high-stage lymphedema as compared to those with lower stages, and improvement was not correlated with the length of time the patient had lymphedema. Their conclusions were limited by the absence of a control group [17]. Kim et al. conducted a retrospective matched cohort study of 60 patients with breast cancer-related lymphedema [12]. Thirty patients underwent sympathetic nerve block while 30 underwent complex decongestive physiotherapy (standard treatment). Both groups were treated for two weeks. The nerve block was conducted three times, once every two weeks. Both groups had significant improvement in limb circumference compared to patient baseline. Interestingly, reduction in limb circumference was higher in the group treated with a nerve block, but the difference was not statistically significant [12].

Prospective Studies

Woo et al. conducted a prospective study of 18 patients with stage II gynecologic cancer-related lymphedema, refractory to treatment [16]. They demonstrated that lumbar sympathetic ganglion block decreased the circumference of affected limbs after three consecutive nerve blocks. Moreover, patients also reported a reduction in pain, tightness, and sensation of heaviness. Their study was limited by the small number of patients and the lack of a control group [16]. Jae Hyeon Park et al. conducted a double-blind, randomized, controlled trial, in which 32 patients with breast cancer-related lymphedema who underwent three consecutive sympathetic nerve blocks, one every two weeks [19]. They divided the patients into three groups: Group A received $0.5 \%$ bupivacaine $5 \mathrm{~mL}$; Group B, $0.5 \%$ bupivacaine $4.5 \mathrm{~mL}$ with $20 \mathrm{mg}$ of triamcinolone $0.5 \mathrm{~mL}$; and Group C, $0.5 \%$ bupivacaine $4 \mathrm{~mL}$ with $40 \mathrm{mg}$ of triamcinolone $1 \mathrm{~mL}$. They demonstrated that sympathetic nerve block significantly decreased the measurements of the affected limbs. Interestingly, Group C obtained a statistically significant reduction in limb circumference as compared to patients in Group A [19]. Myung Woo Park et al. conducted a randomized control trial comparing the effects of a stellate ganglion block with complex decongestive therapy in 38 patients with breast cancer-related lymphedema [13]. They pointed out that both neural block and complex decongestive therapy decreased limb circumference as compared to the baseline. While they did not observe a statistically significant difference between the treatments, their study was limited by the small study population [13].

\section{Discussion}

Although the sympathetic nerve system modulation of the lymphatic system is relatively well-established, few authors have pursued this mechanism to propose targeted therapies in lymphedema treatment [10-1]. In this systematic literature review, we have shown that different authors have published positive clinical outcomes for sympathetic nerve blocks in the treatment of lymphedema. While all papers included in this study were limited by the small number of patients, promising results were found such as a decrease in limb circumference and improvement in patient-reported outcomes (eg, pain). Interestingly, sympathetic nerve block was associated with an improvement comparable with complex decongestive therapy (standard therapy) and was described as an effective therapy for patients with high-stage lymphedema, considered poor candidates for surgical treatments of lymphedema [17]. To our knowledge, this study is the first systematic literature review investigating the use of sympathetic nerve block in lymphedema treatment.

Sympathetic nerve block is a well-established treatment to manage patients with pain in the lower limbs [16]. Nerve blocks can be performed by anesthetic agents or electrical impulses [20-22]. From this literature review, we noticed that all efforts to propose sympathetic nerve block in lymphedema treatment used local anesthetics, such as bupivacaine, whether or not associated with triamcinolone. Interestingly, a prospective study conducted by Jae Hyeon Park et al. demonstrated that the association of bupivacaine with $40 \mathrm{mg}$ of triamcinolone promoted better outcomes as compared to bupivacaine alone [19].

We do recognize the presence of limitations in this study common to systematic reviews, such as the potential for bias in interpreting the data reported in each study. Moreover, we only included studies published in the English language. In spite of these limitations, we feel that this systematic literature review summarized valuable data about the use of sympathetic nerve block in lymphedema treatment, which can guide future studies to advance the field. We encourage further studies on the topic with large prospective randomized clinical trials.

\section{Conclusions}

The pooled publications investigating sympathetic nerve blocks in lymphedema treatment demonstrated positive outcomes. To date, all studies were clinical, using a local anesthetic to conduct the nerve block. Sympathetic nerve block promoted lymphedema improvement in affected limb circumference and patientreported outcomes, such as pain, comparable to complex decongestive therapy. Large randomized clinical trials are still pending, but sympathetic nerve block seems to be a promising alternative for lymphedema patients who do not respond to conservative therapy.

\section{Additional Information}




\section{Disclosures}

Conflicts of interest: In compliance with the ICMJE uniform disclosure form, all authors declare the following: Payment/services info: All authors have declared that no financial support was received from any organization for the submitted work. Financial relationships: All authors have declared that they have no financial relationships at present or within the previous three years with any organizations that might have an interest in the submitted work. Other relationships: This study was supported by the Mayo Clinic Center of Individualized Medicine and Mayo Clinic Robert D. and Patricia E. Kern Center for the Science of Health Care Delivery. *No other disclosures for all authors. .

\section{References}

1. Cormier JN, Askew RL, Mungovan KS, Xing Y, Ross MI, Armer JM: Lymphedema beyond breast cancer: a systematic review and meta-analysis of cancer-related secondary lymphedema. Cancer. 2010, 116:51385149. 10.1002/cncr.25458

2. Mihara M, Hara H, Hayashi Y, et al.: Pathological steps of cancer-related lymphedema: histological changes in the collecting lymphatic vessels after lymphadenectomy. PLoS One. 2012, 7:41126. 10.1371/journal.pone.0041126

3. Kwan ML, Darbinian J, Schmitz KH, Citron R, Partee P, Kutner SE, Kushi LH: Risk factors for lymphedema in a prospective breast cancer survivorship study: the Pathways Study. Arch Surg. 2010, 145:1055-1063. 10.1001/archsurg.2010.231

4. Wynn TA: Cellular and molecular mechanisms of fibrosis . J Pathol. 2008, 214:199-210. 10.1002/path.2277

5. Baker A, Kim H, Semple JL, Dumont D, Shoichet M, Tobbia D, Johnston M: Experimental assessment of prolymphangiogenic growth factors in the treatment of post-surgical lymphedema following lymphadenectomy. Breast Cancer Res. 2010, 12:70. 10.1186/bcr2638

6. Hartiala P, Saarikko AM: Lymphangiogenesis and lymphangiogenic growth factors . J Reconstr Microsurg. 2016, 32:10-15. 10.1055/s-0035-1544179

7. Zampell JC, Elhadad S, Avraham T, Weitman E, Aschen S, Yan A, Mehrara BJ: Toll-like receptor deficiency worsens inflammation and lymphedema after lymphatic injury. Am J Physiol Cell Physiol. 2012, 302:709719. 10.1152/ajpcell.00284.2011

8. Gardenier JC, Kataru RP, Hespe GE, et al.: Topical tacrolimus for the treatment of secondary lymphedema. Nat Commun. 2017, 8:14345. 10.1038/ncomms14345

9. Avraham T, Zampell JC, Yan A, et al.: Th2 differentiation is necessary for soft tissue fibrosis and lymphatic dysfunction resulting from lymphedema. Faseb J. 2013, 27:1114-1126. 10.1096/fj.12-222695

10. Bachmann SB, Gsponer D, Montoya-Zegarra JA, et al.: A distinct role of the autonomic nervous system in modulating the function of lymphatic vessels under physiological and tumor-draining conditions. Cell Rep. 2019, 27:3305-3314. 10.1016/j.celrep.2019.05.050

11. Thornbury KD, McHale NG, McGeown JG: Contribution of lymph formation in the popliteal node to efferent lymph flow following stimulation of the sympathetic chain in the sheep. Exp Physiol. 1990, 75:75-80. 10.1113/expphysiol.1990.sp003387

12. Kim JG, Bae SO, Seo KS: A comparison of the effectiveness of complex decongestive physiotherapy and stellate ganglion block with triamcinolone administration in breast cancer-related lymphedema patients. Support Care Cancer. 2015, 23:2305-2310. 10.1007/s00520-014-2593-5

13. Park MW, Lee SU, Kwon S, Seo KS: Comparison between the effectiveness of complex decongestive therapy and stellate ganglion block in patients with breast cancer-related lymphedema: a randomized controlled study. Pain Physician. 2019, 22:255-263.

14. Swedborg I, Arner S, Meyerson BA: New approaches to sympathetic blocks as treatment of postmastectomy lymphedema. Report of a successful case. Lymphology. 1983, 16:157-163.

15. Asai Y, Mamiya K, Nagashima K, et al.: Effects of lumbar sympathetic ganglion block in a patient with acquired lymphangioma [Article in Japanese]. Masui. 2001, 50:1121-1122.

16. Woo JH, Park HS, Kim SC, Kim YH: The effect of lumbar sympathetic ganglion block on gynecologic cancerrelated lymphedema. Pain Physician. 2013, 16:345-352.

17. Choi E, Nahm FS, Lee PB: Sympathetic block as a new treatment for lymphedema. Pain Physician. 2015, 18:365-372.

18. Kim J, Park HS, Cho SY, Baik HJ, Kim JH: The effect of stellate ganglion block on intractable lymphedema after breast cancer surgery. Korean J Pain. 2015, 28:61-63.

19. Park JH, Min YS, Chun SM, Seo KS: Effects of stellate ganglion block on breast cancer-related lymphedema: comparison of various injectates. Pain Physician. 2015, 18:93-99.

20. Soin A, Shah NS, Fang ZP: High-frequency electrical nerve block for postamputation pain: a pilot study . Neuromodulation. 2015, 18:197-205. 10.1111/ner.12266

21. Emelife PI, Eng MR, Menard BL, Myers AS, Cornett EM, Urman RD, Kaye AD: Adjunct medications for peripheral and neuraxial anesthesia. Best Pract Res Clin Anaesthesiol. 2018, 32:83-99. 10.1016/j.bpa.2018.06.011

22. Cozowicz C, Poeran J, Zubizarreta N, Mazumdar M, Memtsoudis SG: Trends in the use of regional anesthesia: neuraxial and peripheral nerve blocks. Reg Anesth Pain Med. 2016, 41:43-49. 10.1097/aap.0000000000000342 